\title{
Reinstatement of Sphaerolobium minus (Fabaceae: Mirbelieae)
}

\author{
Michael D. Crisp
}

\begin{abstract}
Crisp, Michael D. (Division of Botany and Zoology, Australian National University, GPO Box 4, Canberra ACT 2601 Australia). Reinstatement of Sphaerolobium minus (Fabaceae: Mirbelieae). Telopea 5(2): 335-340. Sphaerolobium minus, synonymised with $S$. vimineum for 180 years, is here reinstated. Both species have been observed growing sympatrically without intergrading. The former is widespread in eastern Australia, occurring along the coast and adjacent ranges in south-east Queensland, New South Wales, Victoria, Tasmania and South Australia, whilst the latter is found in scattered populations from south-east Queensland, New South Wales, eastern Victoria and possibly Western Australia. Some comments are made on the value of observations in the field as opposed to those made purely from herbarium specimens.
\end{abstract}

\section{Introduction}

'Dried herbarium specimens - mere corpses - are ugly and difficult to analyse, and there is much to learn about plant life by its study in field and forest' (Bruhl 1926: vi).

For nearly 200 years, only one species of Sphaerolobium has been recognised along the east coast of Australia. I was surprised, then, to find two species in a mixed population during a recent field trip to the Penrose area in the central tablelands of New South Wales. The plants were flowering and several discontinuities were evident in their floral morphology. I saw no intermediates. If these were two taxa, they were maintaining their distinction in sympatry, and ought to be considered species. Either of two possibilites might account for the occurrence of two species at Penrose: (i) one might be the well-known, widespread S. vimineum, while the other might be a newly discovered narrow-endemic, or (ii) both species might be more widespread but hitherto not distinguished. Subsequent examination of herbarium specimens proved the latter. Why then had their differences been overlooked? In living plants, the most obvious diagnostic characters concern the shapes and colours of the petals. In herbarium specimens, these features have been obscured in pressing and drying. Presumably this is why the taxa had remained undistinguished for so long - hence the quotation above, a salutory reminder for armchair botanists. In fact, herbarium specimens of Sphaerolobium are easily sorted into the two species, but the relevant features are subtle (see below), and I first noticed them in the living plants.

Smith (1805: 509) described Sphaerolobium from a single type, S. vimineum Smith from Port Jackson. Later that year, Labillardière (1805: 108) described S. minus Labill., using a collection of his own from Tasmania. Although he made no comparison with $S$. vimineum, he must have considered S. minus to be different. Presumably it was smaller in some feature, if the name were to be taken literally (more on this below). Subsequent authors virtually ignored $S$. minus. Brown (1811: 14) reduced it to a synonym of $S$. vimineum without explanation. Candolle (1825: 108) followed Brown, as did all subsequent authors, including Bentham (1864: 65), Thompson (1961: 31) and Wiecek in Harden (1991: 472). The only discussion of S. minus that I have seen is a statement by Bentham (1837: 12) that he didn't know the type, and that it might be 
referred to $S$. vimineum, but since these species had not been adequately diagnosed, his opinion was provisional ('mihi incognitum est. Forsan ad unam praecedentium referendum foret, sed adhuc propter diagnosim incompletam inter species non satis notas recensetur").

Sphaerolobium is a distinctive genus, easily diagnosed by its very small, usually caducous leaves and consequent rush-like habit, large round caducous bracteoles, and small globular pods (Smith 1805; Crisp \& Weston 1987). Smith (1805) diagnosed the genus by the membranous-winged style, and Crisp and Weston (1987) cited punctate calyx and bracteoles, but neither feature is seen in all species (Blackall \& Grieve 1954; see also below). Smith actually called the wing a stigma, but he was in error, because the stigma is terminal and clearly separate from the lateral stylar wing (Figure 1e,j). This wing may function instead as a pollen-presenter. These obvious unifying features of Sphaerolobium have masked the differences among species, which are often subtle characters of the flowers. For instance, several taxa differing in petal shapes and colours appear to have been confused under S. macranthum Meissner in Western Australia. It is clear that the number of species is much greater than the 13 currently recognised (Hnatiuk 1990). Currently, two species are recognised in eastern Australia (S. vimineum and S. daviesioides Turcz.) and both are also considered to occur in Western Australia (Blackall \& Grieve 1974; Hnatiuk 1990). The western material referred to $S$. vimineum appears to include more than one species. All specimens I have seen differ from $S$. vimineum in having sulcate to ribbed stems and none may be conspecific with it. However, in some specimens from the Perth region (e.g. Seabrook 317 ) the grooves are subtle, and this population should be compared more closely with eastern S. vimineum. The type of $S$. daviesioides is western and likewise differs from the eastern specimens in having grooved stems, as well as a different branching pattern (shorter, frequently trifid lateral branchlets). Thus the eastern ' $S$. daviesioides', which is restricted to the Grampians in western Victoria, is probably an undescribed species. To summarise, in eastern Australia, there are at least two, and possibly three endemic species of Sphaerolobium.

Two characters readily distinguish $S$. vimineum from $S$. minus, even in dried herbarium material. First, the calyx of $S$. vimineum is minutely dark-spotted (punctate) over a light green background (readily seen with a 10x hand-lens), whereas the calyx of $S$. minus is uniformly lead-grey. Second, the membranous stylar wing of S. vimineum is short ( $<1 / 10$ length of the style) and about as broad as long, whereas that of $S$. minus is narrower and runs $1 / 4$ to halfway down the length of the style (Figure $1 \mathrm{~d}, \mathrm{i})$. In the mixed population at Penrose (vouchers Briggs \& Crisp 2669-70), several additional features distinguish these species, but these are not readily observable from herbarium specimens, and their reliability elsewhere is unclear. First, $S$. minus is smaller both in stature and in all its parts (Figure 1), a feature which agrees with its name. Second, the corolla of S. minus is is virtually pure yellow, in contrast to that of $S$. vimineum, which has a more orange hue, as well as more conspicuous red markings (Rotheram et al. 1975: 37). However, at least some Victorian plants of S. minus appear to have a greater amount of red in their corolla than at Penrose (Cochrane et al., 1973: 34 [as S. vimineum]; Albrecht, pers. comm.). Third, the petals are shaped and held differently - in particular, the standard is narrowed towards the base and the wings are oriented nearly horizontally to expose the keel in S. minus, whereas the standard is broader than long and the wings are oriented more or less vertically to enclose the keel in S. vimineum; also, the wings are equal in length to the obtuse keel in S. minus but longer than the truncate keel in S. vimineum (Figure $1 b, c, g, h$ ). Fourth, in S. minus, the style is sharply flexed down and then upwards again, so that for most of its length it is vertical, whereas in S. vimineum, the style is strongly and evenly curved inwards, going almost full circle. In addition, the style is slightly twisted sideways in S. vimineum. 


\section{Taxonomy}

In the following diagnostic descriptions, measurements are taken from pickled material of the sympatric plants at Penrose, but relative sizes estimated from herbarium specimens are consistent between the species throughout their range, as cited below. $S$. vimineum is coarser in all its parts than S. minus, but this difference is difficult to quantify.

\section{Key to distinguish Sphaerolobium minus from S. vimineum}

1 Calyx and bracteoles darkly punctate; wings longer than and enclosing keel; style with a membranous wing nearly as broad as long and $<1 / 4$ length of style

\section{S. vimineum}

$1^{*} \quad$ Calyx and bracteoles uniformly lead-grey; wings equal to and exposing keel; style with wing much longer than broad, tapering down from apex to $1 / 3$ to $1 / 2$ length of style

2. S. minus

\section{Sphaerolobium vimineum Smith (1805: 509)}

TYPE: Port Jackson, N[ew] S[outh] Wales, J. White, 1793 (holo LINN; iso LIV).

Slender rush-like shrubs to $>1 \mathrm{~m}$ high. Flowers 6-7 mm long; calyx and bracteoles darkly punctate on a light green background; standard transverse-elliptic, c. $6 \mathrm{~mm}$ broad, rich egg-yolk yellow with a pronounced semi-circle of dark red markings that follow veins for a short distance upwards; wings obovate, c. $6 \mathrm{~mm}$ long, oriented c. vertically and enclosing keel; keel truncate, shorter than wings, 4-4.5 mm long. Style strongly and evenly curved almost full circle, somewhat twisted sideways, with a membranous wing only near the apex, wing about as long as broad. Figure 1a-e.

Queensland, New South Wales and Victoria: along the coast and occasionally on adjacent ranges between Wide Bay and Portland (Vic.). Recorded also in south-west Western Australia, but this population may not be conspecific. In swampy heath on sandy peaty soil. Altitude from 0 to $600 \mathrm{~m}$.

Selected SPecimens (37 examined): QueEnsLand: $8 \mathrm{~km}$ NNW of Tin Can Bay township, L.G. Adams 3607 (CANB); Durval, L. Leichhardt (NSW 34585). New South Wales: Laurieton, J.L. Boorman (NSW 34590); $4 \mathrm{~km}$ NW of Penrose, J.D. Briggs 2670 \& M.D. Crisp (CANB, HO, K, MEL, GAUBA, NSW, PERTH); Port Macquarie, E.R. Brown (NSW 34583); La Perouse, R. Coveny $11246 \&$ M. Taylor (NSW, BRI, CBG, K, MEL, MO, PERTH); $8 \mathrm{~km} \mathrm{~S}$ of Mt Imlay, M.D. Crisp 3580 (CBG, NSW, MEL); Jervis Bay, S. Donaldson 83 (CBG); Salvation Creek, Ku-ring-gai National Park, C. Dunn 3 \& J Thomas (NSW). VICTORIA: Gippsland Lakes Coastal Park, A.C. Beauglehole 74835 (MEL 667785): French Island State park, A.C. Beauglehole 71475 (MEL 640043); Wilsons Promontory, Corner Inlet, E. Chesterfield 1988 (MEL 1575209); $100 \mathrm{~m} \mathrm{~W}$ of Marlo airstrip buildings, P. Geary (MEL 691588); Portland, H.B. Williamson (NSW 34620). WESTERN Australia: Helena Valley, J. Seabrook 317 (PERTH, CANB).

\section{Sphaerolobium minus Labill. (1805: 108, t. 138).}

TYPE: 'Habitat in capite Van-Diemen', J.J. Labillardière (holo FI-W; iso BM, W).

Slender rush-like shrubs usually $<50 \mathrm{~cm}$ high. Flowers $5-6 \mathrm{~mm}$ long; calyx and bracteoles uniformly lead-grey; standard broadly obovate, c. $4.5 \mathrm{~mm}$ broad, pure yellow with faint red markings (the standard can be extensively infused with red pigment, but does not show the distinctive pattern described for $S$. vimineum); wings obovate, c. $5 \mathrm{~mm}$ long, oriented nearly horizontally so as to expose keel; keel obtuse, as long as wings, c. $5 \mathrm{~mm}$ long. Style sharply flexed down then up near the base, thus c. vertical and nearly straight for most of its length, not twisted sideways, with a narrow membranous wing tapering downwards from apex to near middle. Figure $1 \mathrm{f}-\mathrm{j}$. 

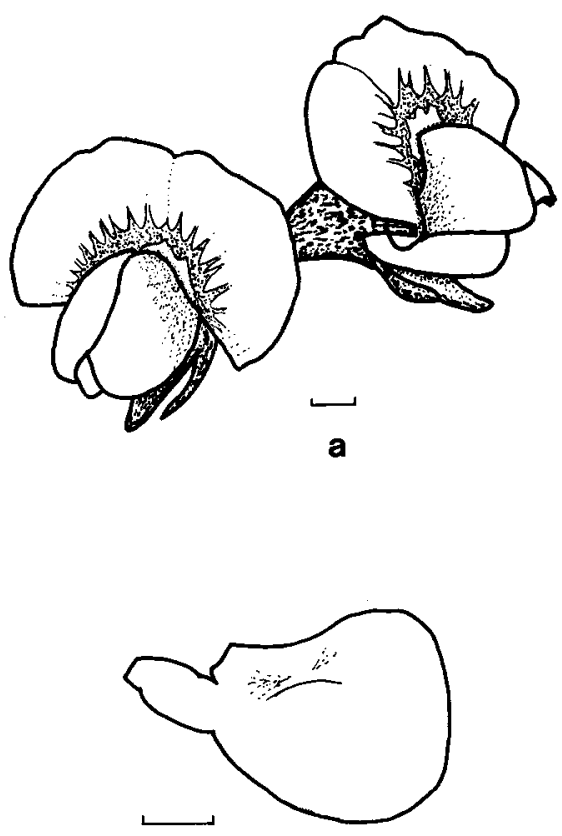

b
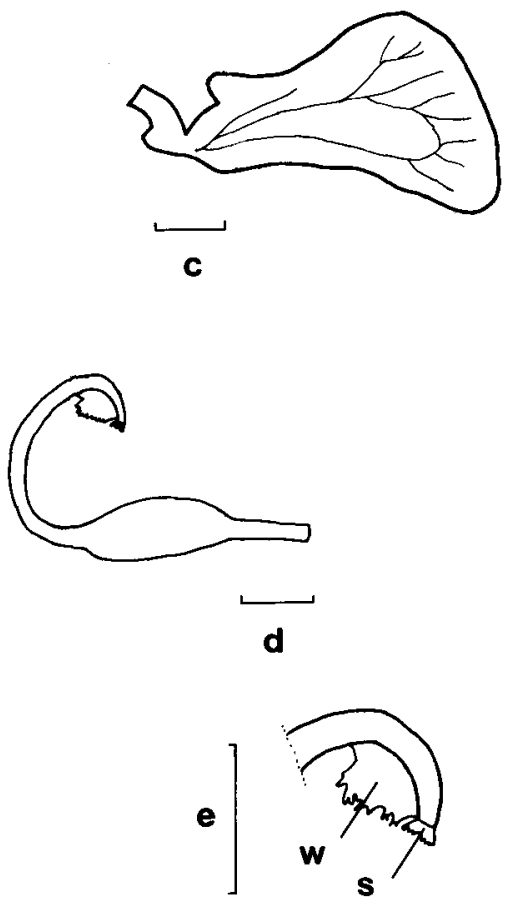

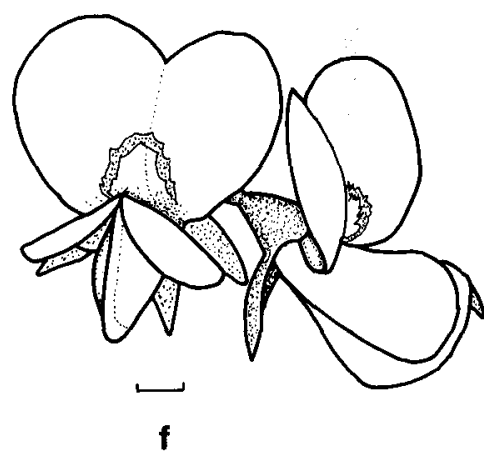

$\mathbf{g}$
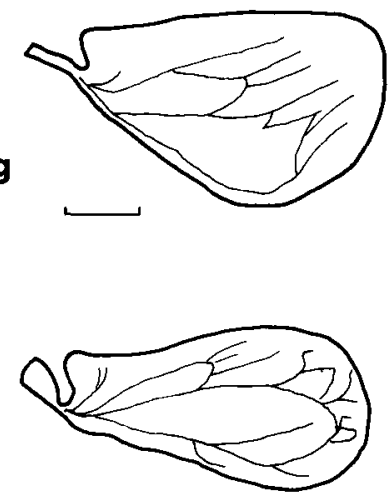

h
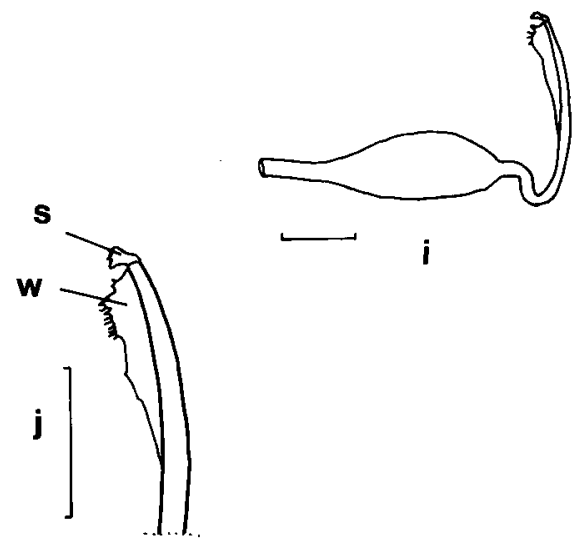

Figure 1. Sphaerolobium vimineum. $\mathbf{a}$, flowers; $\mathbf{b}$, keel; $\mathbf{c}$, wing; $\mathbf{d}$, gynoecium; $\mathbf{e}$, distal portion of style. S. minus: $\mathbf{f}$, flowers; $\mathbf{g}$, keel; $\mathbf{h}$, wing; $\mathbf{i}$, gynoecium; $\mathbf{j}$, distal portion of style. a-e from Briggs 2670 \& Crisp; $\mathrm{f}-\mathrm{j}$ from Briggs 2669 \& Crisp. $\mathbf{s}=$ stigma; $\mathbf{w}=$ stylar wing. All scale bars are $1 \mathrm{~mm}$ long. 
Widely distributed along the coast and adjacent ranges in south-eastern Australia, from south-east Queensland through New South Wales and Victoria, south to Tasmania and west to Eyre Peninsula in South Australia. In wet heath, in sandy or peaty soil, sometimes in forest understorey. Altitude from 0 to $1400 \mathrm{~m}$.

SeleCted SPeCimens: (350 examined): South Australia: Kuitpo Forest, Mt Lofty Range, W. Gill 21 (NSW). New South Wales: 4 km NW of Penrose, J.D. Briggs 2669 \& M.D. Crisp (CANB, HO, MEL, GAUBA, NSW, PERTH); Wentworth Falls, C. Burgess (CBG 15351); Nepean River, Mulgoa, R. Coveny 8491 \& S. Roy (NSW); $30 \mathrm{~km}$ SW of Eden, M.D. Crisp 3586 (CBG, NSW); Nadgee Nature Reserve, N. Fisher 16 (CBG); 10 miles $S$ of Woodburn, D. Shoobridge (CBG 14926); 8 miles NE of Tenterfield, I.R. Telford 2510 (CBG). Australian Capital Territory: Upper Cotter Valley, P. Gilmour 6345 (CBG, NSW). VICTORIA: Towards Arthurs Seat, Mornington Peninsula, I Beeton (CBG 39733); SE of Portland Alcoa smelter site, $1.3 \mathrm{~km} \mathrm{NW}$ of Point Danger, M.D. Crisp 6815 (CBG); Otways, $4 \mathrm{~km}$ NNE of Forrest, S.G. Harris 37 (CBG, MEL); near summit of Mt Guinear on Thomson River Valley Road towards Mt Baw Baw, P. Mc Donnell 422a (CBG); Grampians, $40 \mathrm{~km} \mathrm{~N}$ of Dunkeld, H. Streimann 2905 (CBG). TASMANiA: Rocky Cape Road, $500 \mathrm{~m}$ NE of junction with Bass Hwy, F.E. Davies 1086 (CBG); 1.5 miles from Arthur River towards Marrawah, M.E. Phillips 315 (CBG 31447); between Bicheno and Freycinet Peninsula, M.E. Phillips (CBG 19497).

\section{Acknowledgements}

I wish to thank David Albrecht for providing data from specimens in MEL; Julian Ash for suggesting the quotation; John Briggs for assistance in the field; John Briggs, Bob Makinson and Ian Telford for reading the manuscript; and Helen Thompson for helping with the bibliographic data. Thanks to the heads of herbaria AD, CANB, CBG, HO, MEL and NSW for access to their collections.

\section{References}

Bentham, G. (1837) Commentationes de Leguminosarum Generibus. (J. P. Sollinger: Vienna). Reprinted 1839 as 'De leguminosarum generibus commentationes' in Ann. Wiener Mus. Naturgesch. 2: 61-142.

Bentham, G. (1864) Flora Australiensis, vol. 2. (Reeve \& Co.: London.).

Blackall, W.E. \& Grieve, B.J. (1954). How to know Western Australian wildflowers, part I. (University of Western Australia Press).

Brown, R. (1811) Decandria Monogynia (part). Pp. 8-21 in W. T. Aiton (ed.), Hortus Kewensis, edn 2, vol. 3. (Longman: London.)

Bruhl, P. (1926) A guide to the orchids of Sikkim. (Thacker Spink \& Co: Calcutta \& Simla). Facsimile reprint 1978, Bishem Singh Mahendra Pal Singh: Dehra Dun.

Candoll, A.P. de (1825) Prodromus Systematics Naturalis Regni Vegetabilis, vol. 2. (Treuttel \& Wurtz: Paris.)

Cochrane, G.R., Fuhrer, B.A., Rotheram, E.R. \& Willis, J.H. (1973). Flowers and plants of Victoria, edn 2. (Reed: Sydney).

Crisp, M. D. \& Weston, P. H. (1987) Cladistics and legume systematics with an analysis of the Bossiaeeae, Brongniartieae and Mirbelieae. Pp. 65-130 in C. H. Stirton (ed.), Advances in legume systematics, part 3. (Royal Botanic Gardens: Kew).

Harden, G., ed. (1991) Flora of New South Wales, vol. 2. (University of New South Wales Press: Sydney.)

Hnatiuk, R.J. (1990) Census of Australian vascular plants. (Australian Government Publishing Service: Canberra).

Labillardière, J. J. H. de (1805) Novae Hollandiae Plantarum Specimen, vol. 1, parts 13-14. (Dominae Huzard: Paris.)

Rotheram, E.R., Briggs, B.G., Blaxell, D.F. \& Carolin, R.C. (1975) Flowers and plants of New South Wales and southern Queensland. (Reed: Sydney). 
Smith, J.E. (1805) Remarks on the generic characters of the decandrous papilionaceous plants of New Holland. Annals of Botany (Koenig \& Sims) 1: 501-512.

Thompson, J. (1961) Papilionaceae. In R.H. Anderson, Contributions from the New South Wales National Herbarium, Flora Series, No. 101, part 1.

Manuscript received 7 December 1992

Manuscript accepted 29 January 1993 